\section{Reducing Sprinkler Irrigation Volumes for Strawberry Transplant Establishment in Florida}

\author{
Bielinski M. Santos ${ }^{1,3}$, Teresa P. Salame-Donoso ${ }^{1}$, \\ and Alicia J. Whidden ${ }^{2}$
}

AdDitional INDEX wORDs. Fragaria $\times$ ananassa, water management, best management practices, crop protectants, sun scalding, kaolin clay

Summary. Two field studies were conducted to determine whether foliar kaolin clay applications would reduce water volumes during the establishment of bare-root strawberry (Fragaria $\times$ ananassa) transplants. Transplant establishment treatments resulted from combinations of duration of sprinkler irrigation and foliar application of kaolin clay were: a) 4 days of sprinkler irrigation, b) 4 days of sprinkler irrigation plus kaolin clay on day 5, c) 6 days of sprinkler irrigation, d) 6 days of sprinkler irrigation plus kaolin clay on day 7 , e) 8 days of sprinkler irrigation, f) 8 days of sprinkler irrigation plus kaolin clay on day 9, and g) 10 days of sprinkler irrigation (control). One day of sprinkler irrigation was defined as the application of 8 hours per day of irrigation to ensure plant establishment, using $\approx 6000 \mathrm{gal} / \mathrm{acre}$ per hour of water. Kaolin clay treatments were applied using a rate of $25 \mathrm{lb} /$ acre and on the early morning of the following day after sprinkler irrigation was suspended. Treatments influenced the number of established plants and diameter at 4 and 8 weeks after transplanting (WAT), leaf greenness at 8 WAT, and early and total fruit weight. There were no differences in the number of established plants among treatments that received 10 days of sprinkler irrigation (control), 8 days of sprinkler irrigation followed by kaolin clay on day 9 , and 6 days of sprinkler irrigation followed by kaolin clay on day 7 , ranged between $97 \%$ and $98 \%$ plant survival. The highest strawberry early and total fruit weights (3.6 and 15.7 tons/acre, respectively) occurred in plots transplanted with either 6 days of sprinkler irrigation plus kaolin clay on day 7, 8 days of sprinkler irrigation plus kaolin clay on day 9, or 10 days of sprinkler irrigation. These data indicated that the addition to kaolin clay after 6 or 8 days of sprinkler irrigation improved strawberry establishment, growth, and yields to the same levels as the control treatment, while saving at least $20 \%$ of the water volume needed for establishment.

$\mathrm{F}$ lorida ranks second in the United States in strawberry sales value (\$362 million), and it produces the vast majority of the crop during the winter months [U.S. Department of Agriculture (USDA), 2011]. During the last 10 years, the surface area planted with strawberries in Florida increased from 6300 acres in 2000 to 8800 acres in 2010 (USDA, 2001, $2011)$, and it is expected to surpass 10,000 acres in 2011. Most of the acreage occurred in the Plant City-Dover agricultural area in Hillsborough County, located in the west-central region of the state, where deep sandy soils with rapid infiltration are the norm.

In the Plant City-Dover agricultural area, strawberry fields are in close proximity to urban settings and water

${ }^{1}$ Gulf Coast Research and Education Center, IFAS, University of Florida, 14625 County Road 672, Wimauma, FL 33598

${ }^{2}$ Hillsborough County Extension Office, IFAS, University of Florida, Seffner, FL

${ }^{3}$ Corresponding author. E-mail: bmsantos@ufl.edu. resources are shared between housing developments and production fields using deep fresh water wells. Highimpact sprinkler irrigation ( 4 to $5 \mathrm{gal}$ / min per head) is used during strawberry production for two primary reasons: transplant establishment and freeze protection. For transplant establishment, bare-root plants from northern nurseries are set into fumigated, polyethylene mulched beds and irrigated with sprinklers during
8 to $10 \mathrm{~h}$ per day for the first $10 \mathrm{~d}$ after transplanting (Hochmuth et al., 1993). This practice is performed to reduce the temperature around the young crowns during establishment and to provide enough moisture to new roots in that period. Although this is a traditional strawberry practice in many places around the world, it is highly inefficient because it uses large water volumes (between 14 and 20 acre-inch/acre), most of which ends up running off the polyethylene mulch, then into the row middles, and finally into the drainage canals or leaching to the water table (Bish et al., 1997; Hochmuth et al., 2006).

Furthermore, the current structure of water permits for agriculture in the area allocates certain volumes for production regardless of their purpose (i.e., freeze protection, establishment, and crop maintenance) and those volumes are monitored with water meters. Thus, water savings due to reduced volumes for establishment would allow growers either to save water and pumping costs or more flexibility for other uses during the growing season. One example of the fragility of the current system is that during the unusually cold winters of 2009 and 2010 , many deep wells went temporarily or permanently dried due to overuse of sprinkler irrigation for freeze protection in Hillsborough County [Southwest Florida Water Management District (SFWMD), 2011]. It is estimated that in Jan. 2010, 750 residential wells were impacted and more than 140 sinkholes were reported in this county, which has prompted discussions about more stringent local regulations on water management for strawberry production (SFWMD, 2011). Therefore, establishment practices aiming to reduce water volumes

\begin{tabular}{llll}
\hline $\begin{array}{l}\text { Units } \\
\begin{array}{l}\text { To convert U.S. to SI, } \\
\text { multiply by }\end{array}\end{array}$ & U.S. unit & SI unit & $\begin{array}{l}\text { To convert SI to U.S., } \\
\text { multiply by }\end{array}$ \\
\hline 0.4047 & acre(s) & $\mathrm{ha}$ & 2.4711 \\
254.0000 & acre-inch/acre & $\mathrm{m}^{3} \cdot \mathrm{ha}^{-1}$ & 0.0039 \\
0.3048 & $\mathrm{ft}$ & $\mathrm{m}$ & 3.2808 \\
3.7854 & $\mathrm{gal}$ & $\mathrm{L}$ & 0.2642 \\
0.1242 & gal/100 ft & $\mathrm{L} \cdot \mathrm{m}^{-1}$ & 8.0520 \\
9.3540 & gal/acre & $\mathrm{L} \cdot \mathrm{ha}^{-1}$ & 0.1069 \\
2.54 & inch $(\mathrm{es})$ & $\mathrm{cm}$ & 0.3937 \\
1.1209 & $\mathrm{lb} / \mathrm{acre}$ & $\mathrm{kg} \cdot \mathrm{ha}^{-1}$ & 0.8922 \\
1 & $\mathrm{mmho} / \mathrm{cm}$ & $\mathrm{dS} \cdot \mathrm{m}^{-1}$ & 1 \\
28.3495 & $\mathrm{oz}$ & $\mathrm{g}$ & 0.0353 \\
2.2417 & ton/acre & $\mathrm{Mg} \cdot \mathrm{ha}^{-1}$ & 0.4461 \\
$\left({ }^{\circ} \mathrm{F}-32\right) \div 1.8$ & ${ }^{\circ} \mathrm{F}$ & ${ }^{\circ} \mathrm{C}$ & $\left(1.8 \times{ }^{\circ} \mathrm{C}\right)+32$ \\
& & &
\end{tabular}


for strawberry transplanting are desirable both from the environmental and economic standpoints.

Kaolin clay is a naturally occurring mineral that has been suggested as a means to reduce heat stress in horticultural crops. In fruit crops, previous studies determined that application of kaolin clay solutions to apple (Malus $\times$ domestica) trees significantly reduced heat stress and fruit sunburn (Glenn et al., 2002; Schupp et al., 2002). Jifon and Syvertsen (2003) indicated that kaolin clay application on grapefruit (Citrus paradisi) trees decreased leaf temperature by $3^{\circ} \mathrm{C}$, as well as leaf to air vapor pressure, and improved net carbon dioxide assimilation and yield. Rosati et al. (2007) suggested that kaolin clay application on leaves improved the distribution of photosynthetically active radiation in almond (Prunus dulcis) and walnut (Juglans regia). Spiers et al. (2004) demonstrated that when applied to mature blueberry (Vaccinium corymbosum) plants, kaolin clay increased bud and fruit development, as well as plant growth and fruit yield. Steinman et al. (2007) showed that photosynthesis of coffee (Coffea arabica) was enhanced by $71 \%$, while their yields improved by $100 \%$ in comparison with the nontreated plants.

In vegetable crops, many reports have focused on tomato (Solanum lycopersicum) and pepper (Capsicum annumm) because these crops are sensitive to sun scalding injury. Nakano and Uehara (1996) showed that kaolin clay reduces the stomatal aperture in tomato. Other studies have indicated that application of kaolin clay consistently lowers leaf and fruit temperatures, leaf net assimilation, stomatal conductance, and transpiration, while improving lycopene fruit content, soluble solid content, and marketable yields (Cantore et al., 2009; Pace et al., 2007; Saavedra et al., 2006). In some cases, the application of kaolin clay did not have a direct effect of plant growth, but improved early flowering and fruit yield of pepper (Makus, 2005 ). Other investigations on the effects of foliar applications of kaolin clay showed that the product failed to enhance tomato fruit yield (Kahn and Damicone, 2008). Albregts and Howard (1976) indicated that the use of antitranspirants did not enhance strawberry plant survival, leaf retention, fruit size, or yield. Creamer et al.
(2005) determined that pepper plants treated with kaolin clay showed less water stress and higher photochemical reflectance than nontreated plants during active growth periods, but without significant yield differences.

Preliminary observations in Hillsborough County suggested that kaolin clay-based crop protectants could potentially reduce heat stress during plant establishment. However, formal studies needed to be conducted to confirm this hypothesis. One alternative practice would be reducing the number of days needed of sprinkler irrigation, followed by application of kaolin clay on the foliage to reduce heat stress. The objectives of this study were to determine whether foliar kaolin clay applications would reduce water volumes during the establishment of bare-root strawberry transplants.

\section{Materials and methods}

Two trials were conducted during the 2008-09 and 2009-10 strawberry seasons at the Gulf Coast Research and Education Center of the University of Florida, located in Balm, FL (lat. $27^{\circ} 46^{\prime \prime} \mathrm{N}$, long. $\left.82^{\circ} 13^{\prime} 56^{\prime \prime} \mathrm{W}\right)$. The soil at the experimental site is classified as a Myakka fine sand siliceous hyperthermic Oxyaquic Alorthod. The organic matter content and the soil $\mathrm{pH}$ were $1.5 \%$ and 7.3 , respectively, and were measured 4 weeks before transplanting from random samples collected 6 inches deep in six locations within the experiment site. For organic matter and soil $\mathrm{pH}$ determination, the Walkley-Black and 1:2 soil-towater methods were used, respectively (Mylavarapu, 2009; Nelson and Sommers, 1982). Planting beds were 27 inches wide at the base, 24 inches wide at the top, 10 inches high, and spaced $4 \mathrm{ft}$ apart on centers. In midSeptember of each season, pressed beds were fumigated with methyl bromide plus chloropicrin $(67: 33 \mathrm{v} / \mathrm{v})$ at a rate of $350 \mathrm{lb} /$ acre to eliminate soilborne diseases, nematodes, and weeds in the soil. A standard fumigation rig (PS231 bed presser with 55081 gas knives; Kennco Manufacturing, Ruskin, FL) with three knives per bed delivering the fumigant 8 inches deep was used. Within 1 min of fumigation, beds were covered with black high-density polyethylene mulch (0.7 mil thick), and a single line of drip irrigation tubing $(0.23 \mathrm{gal} / 100 \mathrm{ft}$ per min, 12 inches between emitters;
T-Tape Systems International, San Diego, CA) was buried 1 inch deep on bed centers. The experimental area was equipped with $4 \mathrm{gal} / \mathrm{min}$ sprinklers for frost protection and crop establishment. The water at the experimental site has a $\mathrm{pH}$ of 7.4 and electrical conductivity of $0.4 \mathrm{dS} \cdot \mathrm{m}^{-1}$. On 15 Oct. 2009 and 2010, bare-root 'Straw' berry Festival' transplants (Strawberry Tyme Farms, Simcoe, ON, Canada) were set 15 inches apart in double rows and a distance of 15 inches between rows.

Seven transplant establishment treatments resulted from combinations of duration of sprinkler irrigation and foliar application of kaolin clay: a) $4 \mathrm{~d}$ of sprinkler irrigation, b) $4 \mathrm{~d}$ of sprinkler irrigation plus kaolin clay on day 5, c) 6 d of sprinkler irrigation, d) $6 \mathrm{~d}$ of sprinkler irrigation plus kaolin clay on day 7, e) $8 \mathrm{~d}$ of sprinkler irrigation, f) $8 \mathrm{~d}$ of sprinkler irrigation plus kaolin clay on day 9, and $\mathrm{g}$ ) $10 \mathrm{~d}$ of sprinkler irrigation (control). One day of sprinkler irrigation was defined as the application of $8 \mathrm{~h}$ per day of irrigation to ensure plant establishment, using $\approx 6000$ gal/acre per h of water. Kaolin clay treatments were applied with a handheld foliar sprayer using a rate of 25 lb/acre (Surround WP; Tessenderlo Kerley, Phoenix, AZ) mixed in a water volume of $60 \mathrm{gal} / \mathrm{acre}$. Application occurred along planted beds around 8:00 AM of the following day after sprinkler irrigation was suspended. Treatments were arranged in a randomized complete block design with four replications. Experimental units were 12.5-ft-long bed sections (20 plants per plot). After establishment, plants were irrigated twice per day with one irrigation in the morning between 8:00 and 9:00 $\mathrm{Am}$ and another in the early afternoon from 1:00 to 2:00 PM. After transplant establishment, drip irrigation cycles were 15 min from October to mid-November, $30 \mathrm{~min}$ from mid-November to early December, and $45 \mathrm{~min}$ from early December to the end of the season. Fertigation was applied through drip irrigation lines beginning at $10 \mathrm{~d}$ after transplanting. Fertilization and pest control were achieved following current crop recommendations (Peres et al., 2006).

To assess the effect of the treatments on strawberry growth and development, the number of actively 
growing plants were counted at 4 and 8 WAT and the values were converted to percentage of the control treatment. Plant canopy diameters were measured at 4 and 8 WAT perpendicular to the direction of the rows, using five randomly selected plants per plot but avoiding border plants. The same five plants per plot were sampled during the two diameter observations. Greenness of leaves was measured at 8 WAT with a handheld color meter (SPAD-502; Minolta, Ramsey, NJ), which provides a numerical soil plant analysis development value, ranging from 0 to 80 , where $0=$ white and $80=$ dark green. The same plants used for plant diameter were used to obtain the greenness data and two readings were taken from two of the newest mature leaves on the top of the plant canopies. Early and total marketable fruit weights were collected starting at 8 WAT using every plant of each plot. Early marketable fruit weight was defined as the cumulative marketable weight of the first 10 harvests, whereas total marketable fruit weight consisted of 22 harvests during each season. Fruit were harvested Mondays and Thursdays of each week for 11 weeks, starting on the third week in December of each season. A marketable fruit was defined as a fruit with attached calyx, a minimum of $80 \%$ red surface, over $10 \mathrm{~g}$ in weight, and free of mechanical defects, insects, or diseases. Treatment effects were examined for significance $(P<0.05)$ with the general linear model (Statistix Analytical Software, Tallahassee, FL). Means were compared with a Fisher's protected least significance difference test at the $5 \%$ significance level. Percentages of transplant establishment were transformed with $\arcsin ^{-1}$ before analysis of variance to normalize treatment means.

\section{Results and discussion}

The treatment by season interactions were not significant for the variables under study; thus, the data from the two seasons were combined for analysis. There was a significant treatment effect on the number of established plants at 4 and 8 WAT. In most cases, the foliar application of kaolin clay following sprinkler irrigation improved strawberry transplant establishment. At both sampling dates, there were no differences in the number of established plants among treatments that received $10 \mathrm{~d}$ of sprinkler irrigation (control), $8 \mathrm{~d}$ of sprinkler irrigation followed by kaolin clay on day 9 , and $6 \mathrm{~d}$ of sprinkler irrigation followed by kaolin clay on day 7 , ranging between $97 \%$ and $98 \%$ plant survival (Table 1). In contrast, transplant establishment declined to $87 \%$ and $88 \%$ at 4 and 8 WAT, respectively, when $8 \mathrm{~d}$ of sprinkler irrigation were provided. The application of 6 and $4 \mathrm{~d}$ of sprinkler irrigation further decreased plant survival below $80 \%$ and $60 \%$, respectively (Table 1 ).

The transplant establishment programs also influenced strawberry plant canopy diameters at 4 and 8 WAT. At the early sampling date, the widest plant canopy diameters occurred in plots treated with either 6 or $8 \mathrm{~d}$ of sprinkler irrigation followed by foliar kaolin clay application ( $\approx 23 \mathrm{~cm}$ diameter) and in the control plots (Table 1 ). Reducing sprinkler irrigation to 4,6 , or $8 \mathrm{~d}$ without the application of kaolin clay significantly reduced plant canopy diameters by $\approx 25 \%$ in comparison with $10 \mathrm{~d}$ of sprinkler irrigation. There was no plant diameter change when $4 \mathrm{~d}$ of sprinkler irrigation were used, regardless of kaolin clay application, likely due to excessive dehydration. At 8 WAT, the largest plant diameters ranged between 30 and $34 \mathrm{~cm}$ wide and were found in plots treated with either 10 or $8 \mathrm{~d}$ of sprinkler irrigation or in those with $6 \mathrm{~d}$ of irrigation plus kaolin clay on the seventh day. There was a $26 \%$ decline in plant canopy width when no kaolin clay was applied to plots treated with either 4 or $6 \mathrm{~d}$ of sprinkler irrigation in comparison with the control treatment. The treatments did not affect leaf greenness during the midseason (data not shown), which indicated that the white coating produced by the application of kaolin clay disappeared before 8 WAT, likely due to wind removal of dried particles. These results on the growth variables under study indicated that using kaolin clay after 6 or $8 \mathrm{~d}$ of sprinkler irrigation did not reduce plant establishment, canopy diameters, or leaf greenness, while allowed savings between 20\% and 40\% of the water volume.

There were significant treatment effects on early and total marketable fruit weight. The highest strawberry early fruit weight was achieved in plots transplanted with either $6 \mathrm{~d}$ of sprinkler irrigation plus kaolin clay on day 7, $8 \mathrm{~d}$ of sprinkler irrigation plus kaolin clay on day 9 , or $10 \mathrm{~d}$ of sprinkler irrigation

Table 1. Effects of combinations of establishment programs of bare-root strawberry transplants using duration of sprinkler irrigation and foliar kaolin clay applications on the percentage of established plants, canopy diameter, and early and total fruit weight at Balm, FL, in 2008-09 and 2009-10.

\begin{tabular}{|c|c|c|c|c|c|c|}
\hline \multirow[b]{3}{*}{ Transplant establishment program } & \multicolumn{2}{|c|}{ Established plants } & \multicolumn{2}{|c|}{ Plant diam } & \multirow[b]{2}{*}{ Early fruit wt } & \multirow[b]{2}{*}{ Total fruit wt } \\
\hline & $4 \mathrm{WAT}^{\mathrm{z}}$ & $8 \mathrm{WAT}$ & $4 \mathrm{WAT}$ & 8 WAT & & \\
\hline & \multicolumn{2}{|c|}{$(\%)$} & \multicolumn{2}{|c|}{$(\mathrm{cm})^{\mathrm{y}}$} & \multicolumn{2}{|c|}{$(\text { tons/acre })^{x}$} \\
\hline $8 \mathrm{~d}$ of sprinkler irrigation & $87 \mathrm{~b}$ & $88 \mathrm{~b}$ & $18 \mathrm{~b}$ & $30 \mathrm{ab}$ & $3.0 \mathrm{~b}$ & $14.2 \mathrm{~b}$ \\
\hline $8 \mathrm{~d}$ of sprinkler irrigation + kaolin clay on day 9 & 98 a & 98 a & $22 \mathrm{a}$ & 34 a & $3.6 \mathrm{a}$ & $15.7 \mathrm{a}$ \\
\hline $6 \mathrm{~d}$ of sprinkler irrigation & $78 \mathrm{~b}$ & $75 \mathrm{~b}$ & $17 \mathrm{~b}$ & $26 \mathrm{bc}$ & $2.1 \mathrm{c}$ & $13.5 \mathrm{c}$ \\
\hline $4 \mathrm{~d}$ of sprinkler irrigation + kaolin clay on day 5 & $82 \mathrm{~b}$ & $74 \mathrm{~b}$ & $18 \mathrm{~b}$ & $25 \mathrm{c}$ & $2.3 \mathrm{c}$ & $13.1 \mathrm{c}$ \\
\hline Significance $^{\mathrm{v}}$ & * & * & * & * & * & * \\
\hline
\end{tabular}

${ }^{2}$ WAT $=$ weeks after transplanting.

${ }^{\mathrm{y}} 1 \mathrm{~cm}=0.3937$ inch

${ }^{x}$ Early and total fruit weights were the result of the first 10 and 22 harvests, respectively; 1 ton $/$ acre $=2.2417 \mathrm{Mg} \cdot \mathrm{ha}{ }^{-1}$.

"Values followed by the same letter do not differ based on Fisher's protected least significant difference at the $5 \%$ level.

v* = significant at $P<0.05$. 
and their yields ranged between 3.5 and 3.6 tons/acre (Table 1). The application of only $8 \mathrm{~d}$ of sprinkler irrigation for transplant establishment resulted in a $14 \%$ reduction of early yields in comparison with the control treatment, while shorter durations of sprinkler irrigation during transplanting further decreased both early and total fruit weight. Changes to transplant establishment programs influenced total strawberry fruit weight, with the highest seasonal yields between 15.6 and 15.7 tons/acre (Table 1 ). There were no fruit weight differences in plots treated with $10 \mathrm{~d}$ of sprinkler irrigation and those receiving 6 or $8 \mathrm{~d}$ of irrigation plus kaolin clay. Application of only $8 \mathrm{~d}$ of sprinkler irrigation without the sun protectant resulted in a total fruit weight reduction of $9 \%$. These data clearly indicated that the addition to kaolin clay after 6 or $8 \mathrm{~d}$ of sprinkler irrigation improved strawberry establishment, growth, and yields to the same levels as the control treatment.

Several hypotheses might explain these responses. First, foliar application of kaolin clay may have reduced leaf and crown temperatures by reflecting solar radiation. Second, the product might have decreased evaporation around strawberry crowns and leaf transpiration, thus allowing faster formation of new leaves and roots. Third, a combination of both effects might be occurring. These are supported by previous studies indicating that kaolin clay application reduced high temperature stress and air vapor pressure in other crops (Glenn et al., 2002; Jifon and Syvertsen, 2003; Schupp et al., 2002). Further studies will focus on determining the physiological mechanisms of this response. In summary, foliar application of kaolin clay starting on the seventh day after sprinkler irrigation could save between 3.7 and 5.6 acre-inch/acre of water, which might represent potential water savings of 0.9 to 1.3 billion gal in the 8800 acres of the Plant City-Dover strawberry area in Hillsborough County, FL.

\section{Literature cited}

Albregts, E.E. and C.M. Howard. 1976. Effect of intermittent irrigation and antitranspirants on establishing strawberry transplants on mulch. Proc. Florida State Hort. Soc. 89:85-86.
Bish, E.B., D.J. Cantliffe, G.J. Hochmuth, and C.K. Chandler. 1997. Development of containerized strawberry transplants for Florida's winter production system. Acta Hort. 439:461-468.

Cantore, V., B. Pace, and R. Albrizio. 2009. Kaolin-based particle film technology affects tomato physiology, yield and quality. Environ. Exp. Bot. 66:279288.

Creamer, R., S. Sanogo, O.A. El-Sebai, J. Carpenter, and R. Sanderson. 2005. Kaolin-based foliar reflectant affects physiology and incidence of beet curly top virus but not yield of chili pepper. HortScience 40:574-576.

Glenn, D.M., E. Prado, A. Erez, J. McFerson, and G.J. Puterka. 2002. A reflective, processed-kaolin particle film affects fruit temperature, radiation reflection, and solar injury in apple. J. Amer. Soc. Hort. Sci. 127:188-193.

Hochmuth, G., D. Cantliffe, C. Chandler, C. Stanley, E. Bish, E. Waldo, D. Legard, and J. Duval. 2006. Containerized strawberry transplants reduce establishmentperiod water use and enhance early growth and flowering compared with bare-root plants. HortTechnology 16:46-54.

Hochmuth, G.J., S.J. Locascio, S.R. Kostewicz, and F.G. Martin. 1993. Irrigation method and rowcover use for strawberry freeze protection. J. Amer. Soc. Hort. Sci. 118:575-579.

Jifon, J.L. and J.P. Syvertsen. 2003. Kaolin particle film applications can increase photosynthesis and water use efficiency of 'Ruby Red' grapefruit leaves. J. Amer. Soc. Hort. Sci. 128:107-112.

Kahn, B.A. and J.P. Damicone. 2008 Kaolin particle film product applications before harvest begins may not improve marketable yields of fresh tomatoes. HortTechnology 18:144-147.

Makus, D.J. 2005. Effect of kaolin (Surround) on pepper fruit and seed mineral nutrients. Subtropical Plant Sci. 57:5-9.

Mylavarapu, R.S. 2009. UF/IFAS Extension Soil Testing Laboratory (ESTL) Analytical Procedures and Training Manual. 12 Sept. 2009. <http://edis.ifas.ufl.edu/ SS312>.

Nakano, A. and Y. Uehara. 1996. The effects of kaolin clay on cuticle transpiration in tomato. Acta Hort. 440:233238 .

Nelson, D.W. and L.E. Sommers. 1982. Total carbon, organic carbon, and organic matter, p. 539-579. In: A.L. Page, R.H. Miller, and D.R. Keeney (eds.). Methods of soil analysis. Part 2: Chemical and microbiological properties. Amer. Soc. Agron., Madison, WI.

Pace, B., F. Boari, V. Cantore, L. Leo, S. Vanadia, E. De Palma, and N. Phillips. 2007. Effect of particle film technology on temperature, yield and quality of processing tomato. Acta Hort. 758:287-293.

Peres, N.A., J.F. Price, W.M. Stall, C.K. Chandler, S.M. Olson, T.G. Taylor, S.A. Smith, and E.H. Simonne. 2006. Strawberry production in Florida, p. 375-382. In: S.O. Olson and E.H. Simonne (eds.). Vegetable production handbook for Florida, 2006-2007. Inst. Food Agr. Sci. Publ., Univ. Florida, Gainesville.

Rosati, A., S.G. Metcalf, R.P. Buchner, A.E. Fulton, and B.D. Lampinen. 2007. Effects of kaolin application on light absorption and distribution, radiation use efficiency and photosynthesis of almond and walnut canopies. Ann. Bot. (Lond.) 99:255-263.

Saavedra, G., M. Escaff, and J. Hernandez. 2006. Kaolin effects in processing tomato production in Chile. Acta Hort. 724:191198.

Schupp, J.R., E. Fallahi, and I.J. Chun. 2002. Effect of particle film on fruit sunburn, maturity and quality of 'Fuji' and 'Honeycrisp' apples. Hort Technology 12:87-90.

Southwest Florida Water Management District. 2011. Dover/Plant City Freeze Management Plan. 21 Nov. 2011. <http:// www.swfwmd.state.fl.us/agriculture/ freeze-management>.

Spiers, J.D., F.B. Matta, D.O. Marshall, and B.J. Sampson. 2004. Effects of kaolin clay application on flower bud development, fruit quality and yield, and flower thrips [Frankiniella spp. (Thysanoptera: Thripidae)] populations of blueberry plants. Small Fruits Rev. 4:73-84.

Steinman, S.R., H.C. Bittenbender, and T. Idol. 2007. Analysis of kaolin particle film use and its application on coffee. HortScience 42:1605-1608.

U.S. Department of Agriculture. 2001. Vegetables: 2000 Summary. 21 Nov. 2011. <http://usda01.library.cornell. edu/usda/nass/VegeSumm//2000s/ 2001/VegeSumm-02-07-2001.pdf>.

U.S. Department of Agriculture. 2011. Vegetables: 2010 Summary. 21 Nov. 2011. <http://usda01.library.cornell. edu/usda/nass/VegeSumm//2010s/ 2011/VegeSumm-01-27-2011.pdf>. 